African Crop Science Journal by African Crop Science Society is licensed under a Creative Commons Attribution 3.0 Uganda License. Based on a work at www.ajol.info/ and www.bioline.org.br/cs DOI: http://dx.doi.org/10.4314/acsj.v24i3.9

\title{
FIELD TOLERANCE OF SELECTED VARIETIES TO AND FUNGICIDE EFFICACY AGAINST ALTERNARIA BLIGHT OF SWEET POTATO
}

\author{
S.D. KANDOLO ${ }^{1,5}$, A.H. THOMPSON ${ }^{1}$, F.J. CALITZ ${ }^{3}$, S.M. LAURIE ${ }^{1}$, M. TRUTER ${ }^{1,3}$, J.E. VAN DER \\ WAALS ${ }^{5}$ and T.A.S. AVELING ${ }^{5,6}$ \\ ${ }^{1}$ Agricultural Research Council, Vegetable and Ornamental Plant Institute, Private Bag X293, Pretoria 0001, \\ South Africa \\ ${ }^{3}$ Agricultural Research Council, Biometry Division, 1134 Park Street, Hatfield, Pretoria 0083, South Africa \\ ${ }^{4}$ Agricultural Research Council, Plant Protection Research Institute, Private Bag X134, Pretoria 0001, \\ South Africa \\ ${ }^{5}$ Department of Plant and Soil Sciences, University of Pretoria, Pretoria 0028, South Africa \\ ${ }^{6}$ Forestry and Agricultural Biotechnology Institute, University of Pretoria, Pretoria 0028, South Africa
}

Corresponding author: terry.aveling@fabi.up.ac.za

(Received 24 August, 2015; accepted 12 August, 2016)

\begin{abstract}
Alternaria blight (AB) of sweet potato (Ipomoea batatas L.), caused by Alternaria spp., was recently reported in South Africa, but is common in southern and eastern Africa. Elsewhere in the world, AB is controlled primarily using resistant varieties. Twenty-five sweet potato varieties/breeding lines, from different origins were assessed for tolerance to $\mathrm{AB}$. The materials were planted in fields having a history of $\mathrm{AB}$ disease and rated for tolerance based on a General Disease Index (GDI), with the lowest scores representing tolerance, and the higher scores representing susceptibility. Variety 199062-1 had the lowest GDI value, and was the most tolerant to AB; while W119 had the highest GDI value and was the most susceptible to the disease. Other varieties/breeding lines showed a variation in GDI values between most tolerant and most susceptible. Among the fungicides tested under field conditions, the mixture azoxystrobin-difenoconazole was the most effective in reducing AB intensity. Fungicides pyraclostrobin-boscalid, unizeb, azoxystrobin-chlorothalonil and cymoxanil-mancozeb were also effective against the disease.
\end{abstract}

Key Words: Alternaria bataticola, General Disease Index, Ipomoea batatas

\section{RÉSUMÉ}

L'alternariose (AB) de la patate douce (Ipomoea batatas L.), maladie causée par Alternaria spp., est une maladie nouvellement rencontrée en Afrique du Sud, mais très fréquemment rencontrée dans les pays au Sud et à l'Est de l'Afrique. Ailleurs dans le monde, l'utilisation de variété résistantes est la première mesure de lutte contre les dégâts causés par AB. Vingt cinq variétés de patate douce de diverses origines ont été évaluées pour leur sensibilité à l'alternariose. Le matériel génétique avait été planté dans des champs ayant une fois infectés de $\mathrm{AB}$ et classés tolérants en fonction de leur index général de la maladie (GDI). Les plus petits scores indiquent la tolerance, tandis que les scores les plus élevés indiquent la susceptibilité. La variété 199062-1 avait la plus petite de GDI et donc était le plus tolerant à $\mathrm{AB}$, tandis que la variété W119 présentait la valeur de GDI la plus élevée; par conséquent était la plus susceptible de toutes les variétés. Les autres variétés étaient différentes en ce qui concerne leur GDI, les valeurs de GDI variaient du plus petit au plus grand. Parmi les fongicides testés, le mélange azoxystrobin- 
difenoconazole était le plus efficace. Les fongicides pyraclostrobin-boscalid, unizeb, azoxystrobin-chlorothalonil et cymoxanil-mancozeb étaient aussi efficace contre l' alternariose.

Mots Clés: Alternaria bataticola, index général de la maladie, Ipomoea batatas

\section{INTRODUCTION}

Sweet potato (Ipomoea batatas L.) is the sixth most important food crop in the world, with 105 metric tonnes produced annually. Of this, $95 \%$ is grown in developing countries (FAOSTAT, 2009). Orange-fleshed sweet potato varieties are particularly important for having a high betacarotene content, which helps to alleviate vitamin A deficiency in children, especially in rural areas of Kenya (Lopes and Boiteux, 1994; Mwanga and Ssemakula, 2001).

Alternaria blight (AB) is a serious disease of sweet potato in Central, Eastern and Southern Africa (Van Bruggen, 1984; Anginyah et al., 2001; Kapinga and Carey, 2003; Osiru et al., 2007). In Uganda, AB is ranked the most important constraint to sweet potato production (Anginyah et al., 2001). AB was first reported from South Africa by Narayanin et al. (2010a) and has a localised distribution (Thompson et al., 2011). Alternaria bataticola Ikata ex W. Yamamoto has been observed to be the main causal pathogen (Lopes and Boiteux, 1994; Osiru et al., 2008) while A. alternata Fries (Anginyah et al., 2001) and $A$. capsici-annui Savul. and Sandu (Sivaprakasam et al.,1977) also induce AB symptoms on sweet potato (Anginyah et al., 2001).

Since the disease is favoured by wet, humid conditions (Ames et al., 1997; Osiru et al., 2009), and median temperatures of $28^{\circ} \mathrm{C}$ (Osiru et al., 2007), it has the potential to develop in certain sweet potato production areas of South Africa, and should, therefore, be considered a potential threat to the sweet potato industry in the country.

In most countries, control of $\mathrm{AB}$ of sweet potato is limited, with the disease being managed primarily by planting resistant varieties (Anginyah et al., 2001; Mwanga et al., 2003; Osiru et al., 2009). In South Africa, a preliminary glasshouse study showed variation in Alternaria blight levels among sweet potato varieties (Narayanin et al., 2010b). Use of pyrimethanil, cyprodinil, fludioxonil, azoxystrobin, difenoconazole and potassium bicarbonate as control measures has been used with success in the USA (Olson et al., 2012). The objective of this study was to evaluate a wide range of sweet potato varieties/breeding lines from different origins under field conditions for tolerance to $\mathrm{AB}$, and screening for efficacy of selected fungicides against $\mathrm{AB}$.

\section{MATERIALS AND METHODS}

Study locations. The study was conducted from 2010-2012, at two sites, namely Roodeplaat experimental farm of the Agricultural Research Council, Vegetable and Ornamental Plant Institute (ARC-VOPI) (latitude 25,60398; longitude 28,35429; altitude $1168 \mathrm{~m}$ ), Pretoria, Gauteng, South Africa, and at the Owen Sithole College of Agriculture (OSCA), Empangeni (latitude 28,72496; longitude 31,89813; altitude $105 \mathrm{~m}$ ), KwaZulu-Natal, South Africa. At ARC-VOPI only one variety/breeding line was assessed (20102011 season) as very low disease intensity in the second growing season (2011-2012) made the disease assessment not possible. On the other hand, the fungicide study was conducted at Bronkhorstspruit, Gauteng, South Africa and ARC-VOPI from 2012-2014.

Variety/breeding line field trials. Disease-free cuttings of 25 sweet potato varieties/breeding lines, of different origin; were manually planted. A $9 \mathrm{~m}$ long ridge (plot) was used, with betweenridge spacing of $1 \mathrm{~m}$, and in-ridge spacing of 30 $\mathrm{cm}$. Each plot was replicated three times, in a randomised complete block design. The betweenplot ridges and border ridges were planted with a mixture of varieties A15 and Excel, both reported to be susceptible to $\mathrm{AB}$ under greenhouse conditions (Narayanin et al., 2010b). The study at both ARC-VOPI and OSCA was conducted in fields having a history of $\mathrm{AB}$ disease. Plants received overhead irrigation for two hours in the evening (18.00 - $20.00 \mathrm{hr}$ ), twice a week, starting three months after planting to induce optimal conditions for development of $\mathrm{AB}$. 
Fields were fertilised with NPK of 18.5:0:18.5 at $500 \mathrm{~kg} \mathrm{ha}^{-1}$, applied one day before planting; while limestone ammonium nitrate (LAN, 28\%) was applied as a top-dressing three weeks later at $120 \mathrm{~kg} \mathrm{ha}^{-1}$. Weeds were removed manually using hand-hoes. Owing to seasonal differences of the localities, experiments were conducted from December to April and February to June at ARCVOPI and OSCA, respectively.

Fungicide field evaluation. A randomised complete block design, with three replicates, was used. Disease-free cuttings of variety W 119, which is susceptible to AB (Narayanin et al., 2010 b), were manually planted. Each ridge (representing a fungicide treatment plot) was delimited by two border ridges. Details concerning all fungicides are shown in Table 1. As mentioned above, the ARC-VOPI field trial site had a history of $\mathrm{AB}$; while the Bronkhorstspruit field trial site was a new field. Accordingly, plants at Bronkhorstspruit were artificially inoculated in the evenings, by placing $\mathrm{AB}$ diseased leaves on top of the canopy (three infected leaves per spot) at three equally distant points (approx. $2.30 \mathrm{~m}$ from each other) per ridge, and overhead irrigated in the evening (16:00-18:00 hr), twice a week to promote natural Alternaria infection. Fertiliser application and field maintenance were similar to those used for the variety field trials.

Fungicides were applied when $\mathrm{AB}$ symptoms first appeared, and this was repeated every 10 days using a knapsack sprayer. The untreated control plants received only sterile distilled water. Fungicides were applied four and three times at the ARC-VOPI and the Bronkhorstspruit trials, respectively. Plants were not watered for $24 \mathrm{hr}$, following each fungicide application to reduce wash-off.

Disease assessment. Alternaria infection was too low during the first three months of the growing seasons, to assess the area under the disease progress curve, which entails repeated disease assessments (Jeger and Viljanen-Rollinson, 2001). Thus, disease assessment was conducted once at the end of the growing season when disease levels were highest.

For each plot, three equally distant (approx. $2.3 \mathrm{~m}$ from each other) sampling points were taken, with the two outer sampling points located one metre from both ends. In the variety study, both leaves and stems were assessed; while in the fungicide trial plots, only leaves were assessed as AB symptoms developed poorly on the stems.

An open, wooden frame $(47 \mathrm{~cm} \mathrm{x} 47 \mathrm{~cm})$ was used to assess leaf disease severity. The frame was placed on top of the canopy at each sampling point. Fully developed leaves inside the frame were rated using the Ordinal Disease Rating scale of 0-4 based on area of leaf necrosis; where $0=$ no disease; $1=<25 \%$ covered by small spots $(\sim 1 \mathrm{~mm}$ diameter, no yellowing, no abaxial veinal necrosis; $2=25-50 \%$ covered by larger spots $(\sim 2-$ $3 \mathrm{~mm}$ diameter), no yellowing, mild veinal necrosis; $3=>50 \%$ covered, extensive smaller

TABLE 1. Fungicides used in field trials to test for efficacy against Alternaria blight of sweet potato at two locations in South Africa

\begin{tabular}{|c|c|c|}
\hline Active ingredients & Dosage & Type of fungicide \\
\hline Azoxystrobin-chlorothalonil & $1.25 \mathrm{ml}^{100 \mathrm{ml}^{-1}}$ & Systemic/preventive \\
\hline Azoxystrobin-difenoconazole & $375 \mathrm{ml}^{100 \mathrm{ml}^{-1}}$ & Systemic/contact \\
\hline Pyraclostrobin-boscalid & 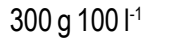 & Systemic \\
\hline Cymoxanil-mancozeb & $3 \mathrm{~kg} 100 \mathrm{l}^{-1}$ & Preventive \\
\hline Copper hydroxide & $350 \mathrm{ml}^{100 \mathrm{ml}^{-1}}$ & Preventive \\
\hline Copper hydro. Equiva & $150 \mathrm{ml}^{100 \mathrm{l}^{-1}}$ & Preventive \\
\hline Potassium phosphate & $2|100|^{-1}$ & Systemic \\
\hline Maneb-zinc oxide & $320 \mathrm{ml}^{100 \mathrm{ml}^{-1}}$ & Preventive \\
\hline Mancozeb & 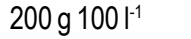 & Preventive \\
\hline Tap water & & \\
\hline
\end{tabular}

aCopper hydro. Equiv = Copper hydroxide equivalent 
spots; or a few large spots with a target pattern, extensive veinal necrosis, partial leaf yellowing; 4 = complete yellowing, necrotic, leaves dying and falling off.

For each variety, nine sampling points were taken, with $\sim 225$ individual leaves assessed and a total of $\sim 5625$ individual leaves assessed for all varieties per field trial. At both fungicide study sites, twenty individual leaves were assessed per sampling point, with 1200 individual leaves assessed for the entire experiment.

A wooden frame of $47 \mathrm{~cm} \times 47 \mathrm{~cm}$, subdivided into nine equal sub-squares with taut wire $(0.7$ mm diameter), was used to assess stem disease severity. The frame was placed at the same sampling points used to assess leaf diseases. The same ordinal rating scale described above was used to rate the percentage of infected stems. A single, ordinal rating was given for all the stems within each sub-square. For each variety, 81 subsquares were assessed, with a total of $\sim 2025$ subsquares assessed for all varieties per field trial.

Statistical analysis.The stem and leaf disease ratings were subjected to a General Linear Model (GLM) technique, with a logistic link function. The maximum likelihood estimators (XBeta's) were calculated as index values on an underlying scale (McCullagh and Nelder, 1989). These estimators (location values) were on an interval scale, from negative to positive values, and were added together to produce the General Disease Index (GDI) means, whose values expressed the level of susceptibility/tolerance of varieties/ breeding lines to $\mathrm{AB}$. Ranking of varieties and breeding lines was based on GDI values, with the lowest being the most tolerant, and the highest the most susceptible. The variance of each experiment was tested for comparable magnitude, using Levene's test (Levene, 1960), before the analysis of combined data was performed. There was a strong evidence for homogeneity of variances between localities (Table 4); therefore, a weighted analysis of combined data was performed (John and Quenouille, 1977). Fisher's t-Least Significant Difference (LSD) was calculated to compare means of significant effects at $5 \%$ significance level (Snedecor and Cochran, 1967). Analysis was performed using SAS/Stat Version 9.2 Statistical Software (SAS, 1999).

\section{RESULTS}

Field study. High $\mathrm{AB}$ disease levels were naturally present at both field trial sites at the end of both growing seasons (Table 3). GDI values for the different varieties/breeding lines varied continuously from -7.229 to 4.555. Three groups emerged based on GDI values viz. tolerant, intermediate and susceptible. 199062-1 was the most tolerant variety/breeding line (GDI-7.229), followed by Muvhelo, 2007-3-10 and Impilo. W119 was the most susceptible variety (GDI 4.555) (Table 3). Varieties/breeding lines with intermediate tolerance included Bophelo, 20045-2, Purple Sunset, 2002-8-2, Monate, Ndou, 20071-3 and 2007-2-12.

In addition, there were significant differences in disease levels between localities and between growing seasons (Table 4). During the 2010-2011 growing season, the OSCA field trial recorded a significantly higher disease severity than ARCVOPI field trial. In the 2011-2012 growing season, the infection level was very low at ARC-VOPI field trial and data could not be analysed statistically. The disease severity was significantly higher at OSCA field trial in 2011 than in 2012 (Table 4).

Fungicide study. Table 5 shows the performance of selected fungicides against $\mathrm{AB}$. The first symptoms of $\mathrm{AB}$ appeared 2 months after planting. Results from the three field trials showed that azoxystrobin-difenoconazole was the most effective fungicide treatment. Pyraclostrobinboscalid, mancozeb, azoxystrobin-chlorothalonil and cymoxanil-mancozebshowed intermediate fungicide efficacy, while copper-hydroxidecopper equivalent was the least effective.

\section{DISCUSSION}

The Owen Sithole College of Agriculture trial site experienced a mean maximum relative humidity of $95 \%$ and the optimum temperature of $28^{\circ} \mathrm{C}$ in both seasons (Table 2). It is likely that these conditions were suitable to the spread of $\mathrm{AB}$ as 
TABLE 2. Temperature, rainfall and relative humidity values at ARC-VOPI and OSCA from December to April 2010-2012 and February to June 2011-2012, respectively

\begin{tabular}{lccrrr}
\hline Parameter & \multicolumn{2}{c}{ ARC-VOPI $^{\mathrm{a}}$} & & \multicolumn{2}{c}{ OSCA $^{\mathrm{b}}$} \\
\cline { 2 - 3 } \cline { 5 - 6 } & $2010 / 2011$ & $2011 / 2012$ & & 2011 & 2012 \\
\hline Mean maximum temperature $\left({ }^{\circ} \mathrm{C}\right)$ & 28 & 29 & & 28 & 28 \\
Mean minimum temperature $\left({ }^{\circ} \mathrm{C}\right)$ & 15 & 15 & & 17 & 17 \\
Total rainfall (mm) & 888 & 420 & & 277 & 155 \\
Mean maximum relative humidity $(\%)$ & 91 & 89 & & 95 & 95 \\
Mean minimum relative humidity $(\%)$ & 39 & 32 & & 48 & 49 \\
\hline
\end{tabular}

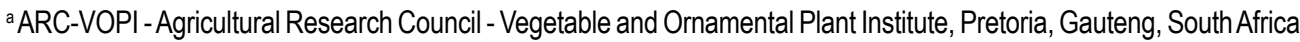
${ }^{b}$ OSCA-Owen Sithole College of Agriculture, Empangeni, KwaZulu-Natal, South Africa

TABLE 3. Sweet potato variety/breeding lines assessed for Alternaria blight disease severity (2010-2012), expressed as General Disease Index means using an interval scale

\begin{tabular}{|c|c|c|c|c|}
\hline $\begin{array}{l}\text { Variety/ } \\
\text { breeding line }\end{array}$ & Origin & Type & Tuber colour & $\begin{array}{l}\mathrm{GDl}^{\mathrm{a}} \\
\text { and t-grouping }\end{array}$ \\
\hline W119 & USA & Variety & Orange & $4.555 \mathrm{a}$ \\
\hline 2004-3-9 & ARC-VOPI ${ }^{b}$ & Line & Orange & $4.342 \mathrm{a}$ \\
\hline $2004-9-1$ & ARC-VOPI & Line & Orange & $4.316 \mathrm{a}$ \\
\hline Excel/A15 & $U^{\prime} A^{c} / U_{K Z N^{d}}$ & Varieties & Orange/Orange & $4.173 a$ \\
\hline Resisto & USA & Variety & Orange & $4.155 \mathrm{a}$ \\
\hline Isondlo & ARC-VOPI & Variety & Orange & $4.028 \mathrm{a}$ \\
\hline Hernandez & USA & Variety & Orange & $3.88 \mathrm{a}$ \\
\hline $2004-16-1$ & ARC-VOPI & Line & Orange & $3.504 \mathrm{a}$ \\
\hline Beauregard & USA & Variety & Orange & $3.489 a$ \\
\hline $2004-3-1$ & ARC-VOPI & Line & Orange & $3.232 a b$ \\
\hline Blesbok & ARC-VOPI & Variety & Cream & $3.174 a b$ \\
\hline $2004-9-2$ & ARC-VOPI & Line & Orange & $2.96 a b$ \\
\hline $2003-23-6$ & ARC-VOPI & Line & Orange & $2.849 a b$ \\
\hline Bophelo & ARC-VOPI & Variety & Orange & $-0.502 \mathrm{~cd}$ \\
\hline $2004-5-2$ & ARC-VOPI & Line & Orange & $-0.665 c d$ \\
\hline Purple sunset & ARC-VOPI & Variety & Orange & -0.805 cde \\
\hline $2002-8-2$ & ARC-VOPI & Line & Orange & -1.521 cde \\
\hline Monate & ARC-VOPI & Variety & Cream & -1.6 cde \\
\hline Ndou & ARC-VOPI & Variety & Cream & -1.781 cde \\
\hline 2007-1-3 & Uganda & Line & Orange & -2.707 cde \\
\hline $2007-2-12$ & Uganda & Line & Orange & -3.034 cde \\
\hline Impilo & ARC-VOPI & Variety & Orange & -3.3 def \\
\hline $2007-3-10$ & Uganda & Line & Orange & -4.087 def \\
\hline Muvhelo & ARC-VOPI & Variety & Cream & $-6.553 \mathrm{def}$ \\
\hline $199062-1$ & $\mathrm{CIPe}$ & Variety & Orange & $-7.229 \mathrm{def}$ \\
\hline $\operatorname{LSD}(P=0.05)$ & & & & 3.35 \\
\hline
\end{tabular}

$\mathrm{t}$-Grouping = Values followed by the same letter do not differ significantly according to Student's $\mathrm{t}$-Least significant difference test $(P<0.05)$

${ }^{\mathrm{a} G D I}$ - General Disease Index; ${ }^{b A R C-V O P I}$ - Agricultural Research Council-Vegetable and Ornamental Plant Institute, Pretoria,

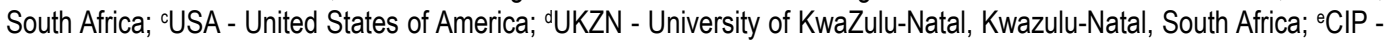
International Potato Centre; LSD - Least Significant Difference 
this site recorded higher Alternaria infection than the ARC-VOPI trial site. Rotem et al. (1989) showed the role of high humidity in inducing Alternaria infection. Similarly, Pleysier et al. (2006) reported that humidity and temperature significantly influenced the infection of $A$. alternata on Paulownia fortunei (Seem.) Hemsl. However, the disease did not develop well at ARCVOPI in the second growing (2011-2012). Several factors can lead to a decrease in disease severity at a given site including humidity, temperature,

TABLE 4. Alternaria blight of sweet potato disease severity expressed as General Disease Index (GDI) means on an interval scale at two locations

\begin{tabular}{lrl}
\hline Location & GDI & t-Grouping \\
\hline OSCA $2011^{a}$ 2010/2011 & -2.696 & $\mathrm{~b}$ \\
ARC-VOP| $^{\mathrm{b}}$ 201063 & $\mathrm{a}$ \\
OSCA 2012 & 1.807 & $\mathrm{a}$ \\
ARC-VOPI 2011/2012 & - & - \\
& & \\
LSD $(P=0.05)$ & 1.094 & \\
\hline
\end{tabular}

$\mathrm{t}-$ Grouping $=$ Values followed by the same letter do not differ significantly according to Student's t-least significant test $(P<0.05)$ ${ }^{\circ} \mathrm{OSCA}=$ Owen Sithole College of Agriculture, Empangeni, Kwazulu-Natal, South Africa

${ }^{\mathrm{b}} \mathrm{ARC}-\mathrm{VOPI}=$ Agricultural Research Council, Vegetable and Ornamental Plant Institute, Pretoria, South Africa rainfall, sowing date or pathogen virulence (Kumar and Srivastava, 2013).

The results of this study showed the reaction of sweet potato varieties and breeding lines during two growing seasons in different localities. The GDI ranking of varieties against AB showed a wide range of tolerance. The variety 199062-1 was the most tolerant plant material against the disease. 199062-1 originates from Peru and has been also reported tolerant to $\mathrm{AB}$ in various sweet potato growing countries (Sunette Laurie, personal communication). Variety rankings suggested that Muvhelo, Monate, Ndou and Impilo were tolerant to $\mathrm{AB}$ under field conditions. A similar study conducted by Narayanin et al. (2010b) reported these three varieties as being tolerant to $\mathrm{AB}$ under glasshouse conditions. On the contrary, Beauregard, Hernandez, Isondlo, Resisto and Excel showed susceptibility to $A B$ while W119 was the most susceptable variety. These findings are in agreement with Narayanin et al. (2010b) who observed that W119, Excel, Beauregard and Resisto were susceptible to AB under glasshouse conditions. W119 and Resisto are originally from the USA (Kapinga et al., 2010) and are currently cultivated in many African countries including Mozambique, Madagascar and South Africa (Kapinga et al., 2010).

The breeding lines 2007-3-10, 2007-2-12 and 2007-1-3 were tolerant to AB. Little has been

TABLE 5. Field reaction of nine fungicides against $A$ lternaria blight of sweet potato

\begin{tabular}{lccc}
\hline Fungicides & ARC-VOPI $^{\mathrm{a}}$ & Bronkhorstspruit & ARC-VOPI \\
& $2012-2013$ & $2012-2013$ & $2013-2014$ \\
\hline Azoxystrobin-difenoconazole & 0.89 & $0.39 \mathrm{~d}$ & 0.84 \\
Pyraclostrobin-boscalid & 1.16 & 0.54 & 0.93 \\
Mancozeb & 0.94 & 0.57 & 1.26 \\
Azoxystrobin-chlorothalonil & 1.33 & 0.68 & 0.96 \\
Cymoxanil-mancozeb & 1.36 & 0.61 & 1.06 \\
Maneb-zinc oxide & 1.14 & 1.22 & 1.64 \\
Potassium phosphate & 1.29 & 1.61 & 1.64 \\
Copper hydroxide & 2.03 & 1.22 & 1.71 \\
Copper hydroxide-copper equivalent & 2.48 & 2.34 & 1.96 \\
Control & 2.82 & 2.87 & 2.74 \\
& & & 0.38 \\
LSD $(0.05)$ & 0.478 & 0.44 & \\
\hline
\end{tabular}

${ }^{a}$ ARC - VOPI = Agricultural Research Council, Vegetable and Ornamental Plant Institute, Pretoria, South Africa 
published on the reaction of these breeding lines against AB. Moreover, these tolerant materials represent reliable sources of resistance, which can be used in future breeding programs to develop tolerant varieties against $\mathrm{AB}$. Other breeding lines such as 2004-3-1, 2004-16-1 and 2004-9-1 exhibited susceptibility to AB with 20043-9 being the most susceptible. Results from the breeding lines showed that AB disease was not tuber colour-dependent as previously suggested by Van Bruggen (1984) and Du Plooy et al. (2008) who reported that sweet potato with red tubers were more susceptible to Alternaria infection than cream coloured varieties. In this study all tolerant and susceptible varieties/breeding line had the orange tuber colour.

In the fungicide study the mixture azoxystrobin-difenoconazole was the most effective in controlling $\mathrm{AB}$. Both azoxystrobin and difenoconazole have been reported to act as protectant and curative fungicides, respectively against Alternaria solani (Ellis \& Martin) Sorauer (Horsfield et al., 2010). The results of this experiment agrees with research conducted by Reuveni et al. (2002) on A. solani and A. alternata on red deciduous apple which showed that azoxystrobin and difenoconazole were both effective in controlling these two pathogens. A spraying program that incorporates both protectant and curative active ingredients has proved to be effective in reducing plant diseases. The results from this work showed that at both ARC-VOPI and Bronkhorstspruit, plants sprayed with a mixture of pyraclostrobin-boscalid recorded low disease. This finding was echoed earlier by Pasche and Gudmestad (2008) and Gudmestad et al. (2013) in A. solani. However, the continuous use of pyrachlostrobin and boscalid can lead to the rapid development of resistance strains of Alternaria as these compounds have a sitespecific mode of action (Avenot and Michailides, 2007; Avenot et al., 2008). In Australia, farmers are discouraged from applying strobilurin fungicides, to which pyrachlostrobin belongs, consecutively and their use should never exceed four applications per annum (Infopest, 2003).

Data from this study revealed that the mixture cymoxanil-mancozeb was also effective against AB because plants treated with these compounds recorded low disease intensity. Similarly, Catão et al. (2013) also reported this mixture to be effective against A. tomatopila Simmons. Mancozeb is often used in combination with other active ingredients as it has many sites of action, therefore delaying the occurrence of pathogen resistant strains (Gullino et al., 2010). Copper hydroxide and copper hydroxide-copper equivalent were the least effective compounds in controlling $\mathrm{AB}$ among all the fungicides tested during all the growing seasons and at all sites. Similar results were echoed by Raid and Timmer (1999) on A. alternata. To our knowledge currently there is no registered fungicide for Alternaria diseases of sweet potato in South (or southern) Africa. These results provide information for chemical companies indicating the most promising active ingredients that control $\mathrm{AB}$ under field conditions.

\section{ACKNOWLEDGEMENT}

The authors would like to thank the South African Department of Science and Technology (DST) for funding this project. We are grateful for the technical support provided by Ms. Mmapaseka Malebana, Mr. Themba Ngidi and Mr. Andre van den Berg. This work is part of a $\mathrm{PhD}$ research study by the first author.

\section{REFERENCES}

Ames, T., Smit, N.E.J.M., Braun, A.R., O’Sullivan, J.N. and Skoglund, L.G. 1997. Sweet potato: Major pests, diseases, and nutritional disorders. International Potato Center (CIP), Lima, Peru. 81pp.

Anginyah, T.J., Narla, R.D., Carey, E.E. and Njeru, R. 2001. Etiology, effect of soil pH and sweet potato varietal reaction to Alternaria leaf petiole and stem blight in Kenya. African Crop Science Journal 9:287-292.

Avenot, H.F. and Michailides, T.J. 2007. Resistance to boscalid fungicides in Alternaria isolates from pistachio in California. Plant Disease 91:1345-1350.

Avenot, H.F., Morgan, D.P. and Michailides, T.J. 2008. Resistance to pyrachlostrobin, boscalid and multiple resistances to Pristine ${ }^{\circledR}$ (pyrachlostrobin + boscalid) fungicide in Alternaria alternata causing Alternaria blight 
in pistachios in California. Plant Pathology 57:135-140.

Catão, H.C.R.M., Sales, N.L.P., Azevedo, D.M.Q., Flávio, N.S.D.S., Menezes, J.B.C., Barbosa, L.V. and Martinez, R.A.S. 2013. Fungicides and alternative products in the mycelial growth and germination control of Alternaria tomatophila. Idesia 31:21-28.

FAOSTAT. 2009. Food and Agriculture Organization of the United Nation (http:// faostat3.fao.org). Accessed on 25/07/2015.

Gullino, M.L., Tinivella, F., Kemmitt, G.M., Bacci, L. and Sheppard, B. 2010. Mancozeb: Past, present and future. Plant Disease 94:10761087.

Gudmestad, N.C., Arabiat, S., Miller, J.S. and Pasche, J.S. 2013. Prevelance and impact of SDHI fungicide resistance in Alternaria solani. Plant Disease 97:952-960.

Infopest, 2003. Infopest: Pest management information system. Department of Primary Industries, Brisbane, Australia.

Jeger, M.J. and Viljanen-Rollinson, S.L.H. 2001. The use of the area under the diseaseprogress curve (AUDPC) to assess quantitative disease resistance in crop cultivars. Theoretical and Applied Genetics 102:32-40.

John, J.A. and Quenouille, M.H. 1977. Experiments: Design and analysis. $2^{\text {nd }}$ edition. Charles Graffin and Company (Ltd), England. pp. 232-248.

Kapinga, R.E. and Carey, E.E. 2003. Present status of sweet potato breeding for eastern and southern Africa. In: Rees, D., van Oirschot, Q. and Kapinga, R. (Eds.). Sweet potato postharvest assessment: Experience from East Africa. Natural Resource Institute. The University of Greenwich, London, UK.

Kapinga, R.E.,Tumwegamire, S., Nduguru, J., Andrade, M.I., Agili, S., Mwanga, R.O., Laurie, S. and Dapaah, H. 2010. Catalogue of orangefleshed sweet potato varieties for sub-saharan Africa. International Potato Center (CIP), Lima, Peru. 8pp.

Levene, H. 1960. Robust tests for the equality of variance. In: Olkin, I. (Ed.). Contributions to probability and statistics. Palo Alto, CA: Stanford University Press. pp. 278-292.
Lopes, C.A. and Boiteux, L.S. 1994. Leaf spot and stem blight of sweet potato caused by Alternaria bataticola: A new record to South America. Plant Disease 78:1107-1109.

McCullagh, P. and Nelder, J.A. 1989. Generalized Linear Models. $2^{\text {nd }}$ Edition, Chapman Hall, New York. pp. 21-44.

Mwanga, R.O.M. and Ssemakula, G. 2011. Orangefleshed sweet potatoes for food, health and wealth in Uganda. International Journal of Agricultural Sustainability 9:42-49.

Mwanga, R.O.M., Odongo, B., Niringiye, C., Kapinga, R.,Tumwegamire, S., Abidin, P.E., Carey, E.E., Lemaga, B., Nsumba, J. and Zhang, D. 2007. Sweet potato selection releases: Lessons learnt from Uganda. African Crop Science Journal 15:11-23.

Mwanga, R.O.M., Odongo, B., Turyamureeba, B., Alajo, A.,Yencho, G.C., Gibson, R.W., Smit, N.E.J.M. and Carey, E.E. 2003. Release of six sweet potato cultivars (NASPOT 1 to NASPOT 6) in Uganda. HortScience 38:475476.

Narayanin, C.D., Thompson, A.H. and Slabbert, M.M. 2010a. First report of Alternaria blight of sweet potato caused by Alternaria bataticola in South Africa. African Plant Protection 16:7-9.

Narayanin, C.D., Thompson, A.H. and Slabbert, M.M. 2010b. Greenhouse screening of South African sweet potato cultivars and breeding lines for tolerance to Alternaria blight caused by Alternaria bataticola. African Plant Protection 16:10-13.

Olson, S.M., Lamberts, M.L., Dittmar, P.J., Zhang, S. and Webb, S.E. 2012. Sweet potato production in Florida. University of FloridaIFAS Extension, HS738.

Osiru, M.O., Adipala, E., Olanya, O.M., Lemaga, B. and Kapinga, R. 2007. Occurrence and distribution of Alternaria leaf petiole and stem blight on sweet potato in Uganda. Plant Pathology Journal 6:112-119.

Osiru, M.O., Adipala, E., Olanya, O.M., Kelly, P., Lemaga, B. and Kapinga, R. 2008. Leaf petiole and stem blight disease caused by Alternaria bataticola in Uganda. Plant Pathology Journal 7:118-119. 
Osiru, M.O., Olanya, M.O., Adipala, E., Lemaga, B. and Kapinga, R. 2009. Stability of sweet potato cultivars to Alternaria leaf and stem blight disease. Journal of Phytopathology 157:172-180.

Pasche, J.S. and Gudmestad, N.C. 2008. Prevalence, competitive fitness and impact of the F 129 L mutation in Alternaria solani from the United States. Crop Protection 27:427435.

Raid, R.N. and Timmer, L.W. 1999. Citrus, tropical and miscellaneous crop reports. Fungicide and Nematicide Tests 55:570.

Reuveni, M., Sheglov, D., Sheglov, N., Ben-Arie, R. and Prusky, D. 2002. Sensitivity of red delicious apple fruit at various phenologic stages to infection by Alternaria alternata and moldy-core control. European Journal of Plant Pathology 108:421-427.

Rotem, J., Blickle, W. and Kranz, J. 1989. Effect of environment and host on sporulation of Alternaria macrospora in cotton. Phytopathology 79:263-266.
SAS, Institute Inc. 1999. SAS/STAT, User's Guide, Version $9,1^{\text {st }}$ Printing, Volume 2. SAS. Institute Inc, SAS Campus Drive, Cary, North Carolina, USA.

Sivaprakasam, K., Krishnamohan, G. and Kandaswamy, T.K. 1977. A new leaf spot disease of sweet potato. Science and Culture 43:325-326.

Snedecor, G.W. and Cochran, W.G. 1967. Statistical Methods. $6^{\text {th }}$ Edition, The Iowa State University Press, Ames, Iowa, USA. pp. 271275.

Thompson, A.H., Narayanin, C.D., Smith, M.F. and Slabbert, M.M. 2011. A disease survey of Fusarium wilt and Alternaria blight on sweet potato in South Africa. Crop Protection 30: 1409-1413.

Van Bruggen, A.H.C. 1984. Sweet potato stem blight caused by Alternaria sp.: A new disease in Ethiopia. Netherlands Journal of Plant Pathology 90:155-164. 